\title{
North Korea in the 1950s: \\ The Post Korean War Policies and Their Implications
}

\author{
Yong-Pyo Hong \\ (Hanyang University)
}

\section{Content}

I. Introduction

II. The Direction of North Korea's

Postwar Policies

III. Internal Policies for Postwar Rehabilitation
IV. The Policy towards South Korea:

A Peace Offensive

V. Conclusion

- Key Words: North Korea, Kim Il Sung, Postwar Rehabilitation, Political Consolidation, Peace Offensive

\section{【 ABSTRACT】}

The purpose of this study is to examine North Korea's post Korean War policy during the period from 1953 to 1960, and analyze its implication not only for North Korean domestic politics but also for inter-Korean relations.

A close look at developments in the northern half of Korea shows that the Communist regime had indeed given priority to consolidating its political power and restoring the economy, contrary to South Korean charge that the Communists were preparing for another aggression in the guise of a peaceful policy. Although the rebuilding of military capabilities was also one of its main goals, it seems that the North placed less emphasis on a military build-up than on post-war rehabilitation during this period, heavily depending on China and the Soviet Union for its defence.

As for unification policy, Kim Il Sung tried to communize the South through a psychological warfare with peace offensive rather than a military one. The Pyongyang regime waged a political campaign to stir up anti-American and anti-South Korean government sentiment, and attempt to win support from the South Koreans by making North Korea economically attractive. But the Communist regime could not gain any tangible support from the southern populace mainly because of its improper behavior during the Korean War. 


\section{Introduction}

The three years of the Korean War was a bitter experience for both North and South Korea. But Seoul and Pyongyang followed different policy directions after the war. While President Syngman Rhee in the South seemed not to be prepared to commit himself fully to peace, Kim Il Sung in the North appeared to adopt a peaceful policy and set up a long-term plan for economic reconstruction.

President Rhee and his government, who had been strongly opposed to any armistice short of the removal of the Communists from the north, continued to hoist the slogan of "March north and unify Korea!" even after the armistice was signed in July 1953. Basically, he perceived that the Communists were preparing another military attack against the South, and that the DPRK government was trying to cover up its real intention by proposing a 'peaceful' policy. In addition, President Rhee believed that North Korea was trying to buy time in order to regroup and refuel its forces before renewing its aggressio n. 1$)$

Immediately after the end of the war, however, Kim Il Sung emphasized such slogans as "peaceful unification," and "everything for the postwar rehabilitation and development of the national economy to strengthen the democratic base!"2) When Kim insisted on these slogans, did he really mean it, unlike Rhee's perception? If so, why did Kim adopt that particular direction, how did he carry out it, and especially, what was his objective in dealing with the relations with South Korea after the war?

For answering these questions, this paper will examine North Korea's post Korean War policy during the period from 1953 to 1960 , and analyze its implication not only for North Korean domestic politics but also for inter-Korean relations. In order to assess North Korean postwar policy objectively, this paper will use not only North Korean documents, but also archives from the U.S. and Britain.

1) For such views of the Rhee government, see Rhee's speech in August 15, 1953 in R.O.K. Office of Public Information, Taet'ongryong Rhee Syngman paksa tamhwachip [Collection of Statements by President Syngman Rhee], Vol. I, (Seoul: Office of Public Information, 1953), pp. 144-48. See also summary minutes of the American-Korean summit talks in Washington D.C. on July 27, 1954 in U.S. Department of State, Foreign Relations of the United States, 1952-1954, Vol. XV: Korea (Washington, D.C.: Government Printing Office, 1984), pp. 1839-47, July 27, 1954 (hereafter cited as FRUS, 1952-1954, Vol. XV).

2) See Kim Il Sung's speech titled "On the Conclusion of the Armistice Agreement," July 28, 1953, in Kim Il Sung's Works, Vol. 7 (Pyongyang: Foreign Languages Publishing House), pp. 456-462 (hereafter cited as Works with volume number). 


\section{The Direction of North Korea's Postwar Policies}

Immediately after the Korean War ended with the armistice agreement on 27 July 1953, Kim Il Sung set forth political, economic and military tasks for his party, government, and people. They were: (1) to consolidate and develop the "people's democratic system"; (2) to rehabilitate the war-damaged economy rapidly, and to improve the people's living standards; (3) to strengthen the nation's defense potential; and (4) to achieve "peaceful unification" of the country. According to Premier Kim, these tasks were closely related to each other. In his report delivered at the sixth Plenary Meeting of the Central Committee of the Korean Workers' Party (KWP), 5 August 1953, Kim Il Sung said that "most important of all for the accomplishment of the reunification and independence of our country is....to consolidate the democratic base politically, economically and militarily by rallying the patriotic forces of the popular masses." This was the only way to assure national unification and the accomplishment of the "people's democratic revolution," Kim argued.3)

Kim's policy directive, emphasizing peaceful unification, and postwar reconstruction, appeared to result from his experience of the Korean War. First of all, although Kim proclaimed a "victory" in the "Liberation War of the Fatherland," the war proved to be futile.4) It not only failed to produce reunification but also left the North Korean economy devastated. The Korean conflict brought about enormous damage both to North and South Korea, but the former suffered greater destruction owing to the heavy aerial bombardment conducted by the United States.5) According to an American intelligence source, the aerial and naval bombardment during the hostilities destroyed about two-thirds to three-fourths of the prewar industrial transportation and urban residential facilities, and the remaining one-third to one fourth of the prewar industry was not in operation because "the destruction of vital portions of installations was sufficient to render almost the whole installation inoperative."6) As a report produced by the U.S. Embassy in Seoul pointed out, "the air

3) Kim II Sung, Selected Works, Vol. I (Pyongyang: Foreign Languages Publishing House, 1971), p. 419 (hereafter cited as Selected Works with volume number.)

4) In Order No. 470 of the Supreme Commander of the Korean People's Army, issued on July 27, 1953, Kim Il Sung claimed that the fact of the signing of the armistice agreement was a "proof of the military, political and moral defeat of the US imperialist invaders and their lackeys, the Syngman Rhee clique." See Kim Il Sung, "Congratulations on the Great Victory in the Fatherland Liberation War," in Works, Vol. 7, p. 446.

5) Some 635,000 tons of bombs and 32,557 tons of napalm were dropped in the northern part of Korea by the U.S. Air Force, which was larger than the amount of bombs $(503,000$ tons) used against Japanese islands during the Second World War. Cited in Rosemary Foot, A Substitute for Victory: The Politics of Peacemaking at the Korean Armistice Talks (Ithaca and London: Cornell University Press, 1990), p. 208. 
bombing was so devastating that rebuilding North Korean industry is largely a problem of new construction rather than rehabilitation."7) As early as September 1952, the US had already estimated the morale of the North Korean people who were short of food, clothing and housing as "bordering on panic."8)

The political structure of the Kim Il Sung regime was also severely damaged during the three years of the war. As Kim Il Sung admitted, a tremendous number of "fine" party members were killed during the war. In addition, a lot of local leaders were expelled from the party because they proved to be "impure elements, cowards, or spies" particularly during the stage when the U.N. forces marched into North Korea, revealing the political weaknesses of the party. Furthermore, factionalism at top Party levels grew more fiercely, partly because of all those wartime problems.9)

Given this disastrous situation, it is not difficult to see why the North Korean regime advocated a 'reconstruction first' policy after the armistice. The northern Communists had to start the task of building political and economic structures virtually anew at the end of the war.

External circumstances also influenced the formation of North Korean postwar policy. The international atmosphere was improving, and major states favored policies that emphasized stability and peaceful coexistence. Neither the Soviet Union, nor China, nor the United States wanted to become involved in a prolonged or renewed war on the Korean peninsula mainly for domestic reasons in each case. Although President Syngman Rhee in the South continued to adhere to the idea of unification by force and to request U.S. support for his military action, ${ }^{10)} \mathrm{Kim}$ Il Sung might have been aware through the armistice negotiations that the U.S. had been strongly opposed to the resumption of the war. Therefore, a South Korean military attack could be ruled out.11)

6) RG 59, "The North Korean Economy," Intelligence Report, No. 6441, April 14, 1954, Office of Intelligence Research, Department of State, Washington D.C. National Archives (hereafter cited as NA). According to a North Korean report, some 600,000 private dwellings, 8,700 factories, 5,000 schools, and 1,000 hospitals or clinics had been destroyed as a result of the war. Cited in Robert A. Scalapino and Chong-Sik Lee, Communism in Korea, Part I: The Movement (Berkeley: University of California Press, 1972), pp. 413.

7) Cited in Foot, A Substitute for Victory, p. 208.

8) FRUS, 1952-1954, Vol. XV, pp. 467-70, September 1, 1952.

9) Selected Works, Vol. 1, p. 527; Byung Chul Koh, "The Korean War as a Learning Experience for North Korea," Korea \& World Affairs, Vol. 3, No. 3 (Fall 1979), pp. 370-371; RG 59, "Factionalism in the Leadership of the North Korean Regime," Intelligence Report, No. 6559, January 3, 1955, Office of Intelligence Research, Department of State, NA.

10) For this point, see Yong-Pyo Hong, State Security and Regime Security: President Syngman Rhee and the Insecurity dilemma in South Korea (London: Macmillan, 2000), ch. 3.

11) For the analyses of changes in the global policy of the U.S. and the Soviet Union, see John Lewis Gaddis, Strategies of Containment: A Critical Appraisal of Postwar American National Security 
Perhaps this is the reason why Kim Il Sung asserted that "it is wrong to think that war might soon break out again and that peaceful construction could not be undertaken because the armistice does not mean a complete peace." Rather, the party and the entire people should devote all their energies to the postwar rehabilitation and construction, Kim argued, by "taking full advantage of the peace during the armistice."12)

In short, the wartime experience and international environment encouraged Kim Il Sung to adopt a policy which gave priority to fortifying his system politically and economically during the postwar era. The next section will study how Kim's postwar policy unfolded politically, economically, and militarily in North Korea.

\section{Internal Policies for Postwar Rehabilitation}

\section{Rebuilding Political Base}

The Korean Workers' Party, which had been an essential instrument of power in North Korea, was in ruins at the end of the Korean conflict, as noted earlier. Thus, the first task of North Korea in the political consolidation of the "democratic base," was to rebuild the KWP, especially to strengthen the "political and ideological unity" of the party.13) For this purpose, according to U.S. intelligence reports, a training program to re-educate party officials at all levels was intensified after August 1953. The British also saw this political indoctrination program as an effort to rehabilitate Communist ideology in order to increase the "hold of Communism upon every member of the North Korean populace."14) The Pyongyang regime also tried to enlarge the party in terms of numbers, and organize the North Korean masses under its tight control. The number of party members increased from 725,762 at the end of the war to $1,164,945$, or about 12 percent of the total population of North Korea by 1956 according to Kim Il Sung's report. ${ }^{15)}$

In terms of his own power, Kim Il Sung obviously felt the need to consolidate his control, primarily by eliminating other factional leaders and their followers in the KWP

Policy (Oxford: Oxford University Press, 1982); Adam B. Ulam, Expansion and Coexistence: Soviet Foreign Policy, 1917-1973 (New York: Praeger, 1974). For the policies of the U.S., as well as the Communists in the armistice negotiations to end the Korean War, see Foot, A Substitute for Victory.

12) Selected Works, Vol. 1, p. 416-19,

13) Ibid., p. 499.

14) The materials used for the indoctrination were said to be the Rodong Sinmun and Lenin's writings. FO 371/110533, FK 1015/11, 2 February 1954, Public Record House (hereafter cited as PRO).

15) Works, Vol. 10, p. 256. 
who threatened his political position. The KWP had been composed of five main factional elements: (1) Kim Il Sung's personal followers, called the Kapsan group or Kim's partisan group; (2) the returnees from the Soviet Union (Soviet-Koreans); (3) the returnees from China, called the Yenan faction; (4) the non-Communist nationalist group; and (5) the domestic South Korean Communists, who had been active in the South under Pak Hon-yong until they fled to the North in 1948.16)

Before the Korean War, Kim Il Sung first neutralized the numerous, but ineffective, non-Communists in North Korea. In the midst of the war, many key military and party leaders were criticized and eliminated. Among them were the popular Yenan-Korean General Mu Chong, and the Soviet-Korean Party leader Ho Ka-i.17) With the close of the war, Kim Il Sung and his partisan group began to be involved in the purge of Pak Hon-yong and his followers, the most formidable rival of Kim's group in the charge of espionage activities for the US, and the attempted overthrow of the government of the DPRK by military force. ${ }^{18)}$

On 28 December 1955, shortly after the execution of Pak Hon-yong, Kim Il Sung delivered his first speech about juche. The concept of juche partly stemmed from Kim's

16) The factionalism in North Korean politics is well analyzed in Dae-Sook Suh, Kim Il Sung: The North Korean Leader (New York: Columbia University Press, 1988); and Scalapino and Lee, Communism in Korea. In examining factional struggles in the North, the following remarks by Scalapino and Lee should be noted: "To place too much emphasis upon factional affiliation is probably a mistake, especially with respect to the so-called Soviet and Yenan factions. Defectors have often stated that the factional divisions were neither as clear-cut nor as meaningful in all cases as non-Communist sources alleged. Moreover, as a careful survey of this period reveals, increasingly the only meaningful faction was coming to be Kim Il-sung, and the crucial factor, one's personal relationship to Kim, irrespective of one's background. Nevertheless, there were differences in background, educational experience, and even culture that stemmed from the heterogeneous nature of the Korean revolutionary movement. And this did constitute a political problem, as the Korean Communists themselves readily admitted. While factionalism may not have been as important as some South Korean writers have indicated, and undoubtedly involved many more ambivalent and poorly defined factions, it remained a crucial issue in this period." Ibid., pp. 479-80.

17) For the analyses of the prewar factional struggle in North Korea, see Bruce Cumings, The Origins of the Korean War, Vol II: The Roaring of the Cataract, 1947-1950 (Princeton, N.J.: Princeton University press, 1981), pp. 316-320; RG 59, "Factionalism in the Leadership of the North Korean Regime," Intelligence Report, No. 6559, January 3, 1955, Office of Intelligence Research, Department of State, NA.

18) Compared with Kim, Pak represented the mainstream of the Korean Communist revolution. Pak was the best-known Communist in Korea during the Japanese occupation and commanded the support of Communists in both North and South Korea after the liberation. Pak was also chairman of the Korean Communist Party. For detailed analyses of the purge of Pak, see Scalapino and Lee, Communism in Korea, pp. 440-51; Suh, Kim Il Sung, pp. 130-36; Hak-Joon Kim, The Unification Policy of South and North Korea: A Comparative Study (Seoul: Seoul National University Press, 1977), pp. 138-42. 
effort to find a Korean identity as a counterweight to Soviet influence. Around that time, the new leaders of the Soviet Union, who were advocating peaceful coexistence with the west, was downgrading Stalin. This situation was incompatible with Kim's stance. Kim's assertion of juche at this very moment was also closely related to his power struggle against the Soviet-Korean group. In his speech, Kim condemned Park Chang-ok that he had failed to recognize the value of Korean proletarian literature. He also condemned Park Yong-bin, another Soviet-Korean for advocating peaceful coexistence with the west.

In the wake of Khrushchev's "de-Stalinization" speeches at the 20th Congress of the Communist Party of the Soviet Union in February 1956, Kim Il Sung faced a serious challenge. Encouraged by the de-Stalinization campaign in the USSR, the Yenan group led by Choi Chang-ik and Yun Kong-hum, in coalition with the Soviet-Koreans headed by Park Chang-ok, launched a joint attack against Kim Il Sung. They criticized Kim over three issues: (1) his one-man dictatorship; (2) the economic priority he gave to heavy industry at the expense of the Korean people's living standards; and (3) his cronyism and factionalism in the selection of party officials. ${ }^{19)}$ The supporters of Kim Il Sung, however, outnumbered the dissidents, and the latter were expelled from the party and branded as anti-party reactionary elements. According to one source, Peng Te-huai, the Chinese Defense Minister, and Mikoyan, the First Deputy Premier of the Soviet Union, interfered in an attempt to reinstate Choi, Park, and Yun in the KWP. But these three were eventually purged in 1958.20) Finally, in February 1958, Kim Il Sung accused and purged the leader of the Yenan group, Kim Tu-bong, perhaps the most important figure and the first chairman of the KWP under whom Kim Il Sung served as vice-chairman.

Thus, by 1958, Kim Il Sung had successfully consolidated his political power. According to a Japanese analysis in 1961, after the purge of Kim Tu-bong, Kim Il Sung's power became stable to the extent that members of other groups did not exist any longer in the party. In other words, there seemed to be no sign of Kim's regime collapsing from within. ${ }^{21)}$

\section{Reconstructing the Economy}

In August 1953, Kim Il Sung set forth a three-stage economic development program:

19) Scalapino and Lee, Communism in Korea, p. 511.

20) "Leadership in North Korea: Groupings and Motivations," Office of Intelligence Research, U.S. Department of State, 1963, the US Declassified Documents Reference System (1975), no. 28C (hereafter cited as DDRS with year and number).

21) FO 371/158554, "Information for Judgment of North Korean Situation," a paper prepared by the Japanese Ministry of Foreign Affairs on the North Korean situation, 2 August 1961, PRO. 
(1) a preparation stage for overall rehabilitation and construction of the national economy; (2) a three-year plan (1954-1956) for the development of the economy to regain prewar levels in all its branches; and (3) a five-year plan (1957-1961) for the foundation of industrialization. The basic direction for postwar reconstruction, according to Kim, was to give priority to the restoration and expansion of heavy industry.

On February 18, 1957, the North Korean regime announced the "successful over-fulfillment" of its three-year plan, claiming that industrial and agricultural production in North Korea had been restored to prewar levels. During this period, half of the total investments went to industry, and 81.1 percent of the industrial investment was allocated for heavy industry. ${ }^{22)}$ The alleged economic achievement of North Korea during this period was also attributable to the great amount of financial and technical assistance provided by the Sino-Soviet bloc.23)

Regarding North Korea's economic achievement, U.S. intelligence sources argued that while industrial production progressed considerably, agricultural and fishing production was below the originally planned goals under the three-year plan. Owing to the regime's emphasis on heavy industry, the production of consumption goods had improved much less rapidly than overall production levels. The shortage of skilled manpower, one of the regime's major problems, had sharply limited North Korean rehabilitation and continued to slow reconstruction efforts. Thus, according to a US intelligence analysis, the demobilization of military personnel was resorted to, and attempts were made to increase participation of women and children in the labor force.24)

In 1957, the five-year plan was launched. Kim Il Sung suggested that the basic tasks of the plan were to consolidate the "economic foundation of socialism" in North Korea, and to solve the food, clothing, and housing problems facing the people.25) In this period, aid from the Communist bloc was reduced, and therefore, the five-year plan had to be financed mainly by internal savings. In order to finance its ambitious industrial

22) Choson chungang yon'gam [The Korean Central Yearbook] (Pyongyang: Choson chungang tongshinsa, 1961), p. 339. Economic statistics derived from official North Korean data are notoriously unreliable. Their validity is usually considered questionable, and unconfirmed. Therefore, these statistics should serve only as indicators of a general tendency.

23) During this period, 1,000 million rubles were given by the Soviet Union and 800 million yuan (about 1,320 million rubles at the official exchange rate) by China. In general, while the Soviet Union was to play the major role in the construction of the basic industrial complex, China was to provide the North Koreans with sufficient necessities of life, and also played a role in such areas as transport. See Yoon T. Kuark, "North Korea's Industrial Development During the Post-War Period," in Robert A. Scalapino, ed., North Korea Today (New York: Praeger, 1963), p. 61; and Scalapino and Lee, Communism in Korea, p. 530.

24) RG 59, "North Korean Economic Progress under Its Three-Year Plan (1954-56)," Intelligence Report, IR-7058, 19 July 1957, Office of Intelligence Research, Department of State, NA.

25) Selected Works, Vol. 2, pp. 27-28. 
development, it was necessary for the Pyongyang regime to enforce compulsory savings averaging 25 percent of the national income. ${ }^{26)}$ As a result, the utmost sacrifice and perseverance of the populace were necessary. To compensate for the continuing shortage of manpower, Kim devised the "Chollima, or Flying Horse Movement,"27) unquestionably influenced by the Chinese "Great Leap Forward."

According to an announcement by the North Korean government, the five-year plan was fulfilled well ahead of schedule--it had taken only two and a half years. But under this plan, too, while some notable results were achieved in heavy industry, the production levels in light industry and agriculture were low, according to a Japanese assessment. ${ }^{28)}$

The official annual growth rate in industry claimed by North Korea during the period of 1956-1959 was an unparalleled 45 percent. According to one study, which tried to recalculate the growth of the North Korean economy by adjusting the exaggerated figures announced by North Korea, even the recalculated industrial growth rate was still extraordinarily high at 36 percent per annum. ${ }^{29)}$ In comparison with South Korea, as shown in Table 1, the economic growth rate of North Korea was far higher. According to one estimate, in 1959, the GDP per capita of North Korea was $\$ 140$, while that of South Korea was $\$ 81.30$ ) Given these figures, it can be said that North Korea did make significant economic progress, especially in heavy industry, during this period. In addition, by 1958, the collectivization of agriculture was completed, and all private ownership in industry and trade was eliminated. Thus, Pyongyang claimed in 1960 that North Korea had become a "socialist-industrial-agricultural" country. ${ }^{31)}$

[ Table 1] Comparison of Average Growth Rate between North and South Korea, 1953-1960 32

\begin{tabular}{c|c|c}
\hline Items & North Korea & South Korea \\
\hline National income & $21.0 \%$ & $4.9 \%$ \\
\hline National income per capita & $17.1 \%$ & $2.7 \%$ \\
\hline
\end{tabular}

26) Chong-Sik Lee, "Stalinism in the East: Communism in North Korea," in Robert A. Scalapino, ed., The Communist Revolution in Asia: Tactics, Goals and Achievements (Angled Cliffs: Prince Hall, 1965), p. 122.

27) It was a campaign to expand production as rapidly as "a horse that runs one thousand $r i$ per day."

28) See FO 371/158554, "Information for Judgment of North Korean Situation," a paper prepared by the Japanese Ministry of Foreign Affairs, 2 August 1961, PRO.

29) For this calculation, see Pong S. Lee, "Overstatement of North Korean Industrial Growth, 1946-63," Journal of Korean Affairs, Vol. 1, No. 2 (July 1971), pp. 3-14.

30) Fujio Goto, Estimates of the North Korean Gross Domestic Product, 1956-1959 (Kyoto: Kyoto Sangyo University Press, 1990), p. 45.

31) Lee, "Stalinism in the East," p. 122. 
On the other hand, however, it should be noted that the average North Korean worker and peasant remained desperately poor. That is, a considerable gap was developing between gross national product and living standards. This gap was portrayed indirectly by a Western observer who had visited North Korea in 1957: "The actual amount of new building, particularly in Pyongyang, the showpiece of the Government, is impressive.....But most of Pyongyang's population.....are housed in temporary wooden shacks. In his evaluation, living standards in North Korea were noticeably lower than those in neighboring China, Japan, or South Asian countries." ${ }^{33)}$ This assessment was confirmed by another Western visitor who said that: "Conditions in the towns [of North Korea] in general were very backward and shabby compared with Seoul...."34) A defector from North Korea also confessed that due to the poor quality and inadequacy of food, many North Koreans had been suffering from malnutrition. ${ }^{35)}$

In sum, these outside observations suggest that the postwar economic reconstruction of North Korea was concentrated on industrial development at the expense of the living conditions of the people. Whatever the result of economic development, however, it cannot be denied that the North Koreans devoted their time and energy to reconstructing their economy.

\section{Rebuilding the Military}

The main task facing North Korea in the military sector following the armistice was to rebuild its military capabilities, which had been seriously weakened during the Korean War. However, this was not so pressing a task as the goals of economic reconstruction and political consolidation. Thus, until 1962, when Kim Il Sung began to emphasize military preparation, the North Korean government placed relatively less importance on a military buildup than on postwar rehabilitation, depending very heavily for the defense of the country on China and the Soviet Union. Chinese troops were not fully withdrawn from North Korea until 1958. From 1955 to 1959, 200 combat aircraft, 8 naval vessels, and

32) The North Korean growth rates are calculated based on figures in Pong S. Lee, "An Estimate of North Korea's National Income," Asian Survey, Vol. 12, No. 6. (June 1972), pp. 518-26. Lee figured out North Korea's national income based on Kim Il Sung's remarks that national income per capita of North Korea in 1966 was 500 wons-- 1.2 times the per capita national income of 1962. The South Korean growth rates are calculated from figures in the Bank of Korea, Economic Statistics Yearbook, 1962 (Seoul: The Bank of Korea, 1962), pp. 12-13.

33) FO 371/141537, "Reconstruction of North Korea: Wooden Shacks and 'Germs in Jars'," 21 November 1957, PRO.

34) FO 371/127602, "Visit to Pyongyang by General Wigforss, the senior Swedish member of NNSC," 9 September 1957, PRO.

35) FO 371/158554, "PKA Special Interrogation Report," SRI-3, 12 January 1961, PRO. 
15 tanks were supplied to North Korea from the Soviet Union, which was the sole supplier of major weapons up to 1957. After 1958 China also began to deliver MiG-15s and MiG-17s to North Korea. ${ }^{36)}$

[ Table 2] Composition of State Expenditure of North Korea (\%)

\begin{tabular}{c|c|c|c|c|c}
\hline & $\begin{array}{c}\text { National } \\
\text { economy }\end{array}$ & $\begin{array}{c}\text { Social and } \\
\text { Cultural }\end{array}$ & $\begin{array}{c}\text { National } \\
\text { Defence }\end{array}$ & $\begin{array}{c}\text { Administra- } \\
\text { tion cost }\end{array}$ & Total \\
\hline 1953 & 48.4 & 11.3 & 15.2 & 9.7 & 100 \\
1954 & 69.5 & 9.8 & 8.2 & 8.4 & 100 \\
1955 & 74.9 & 9.5 & 6.2 & 6.4 & 100 \\
1956 & 74.3 & 12.7 & 5.9 & 6.1 & 100 \\
1957 & 70.5 & 17.3 & 5.3 & 6.1 & 100 \\
1958 & 70.6 & 18.7 & 4.8 & 5.9 & 100 \\
1959 & 68.3 & 23.7 & 3.7 & 4.2 & 100 \\
\hline
\end{tabular}

Source: Chungang choson yon'gam [The Korean Central Yearbook], 1960, p. 229.

North Korean military expenditures shown in Table 2 demonstrate that North Korea put less emphasis on military preparation than on economic rehabilitation. Although these figures are too low to be credible, these are still useful as an indication of a trend. First, the percentage of defense spending in proportion to the total state budget was reducing throughout the period from 1953 to 1960 . Secondly, it is notable that Pyongyang spent annually only about 5 percent of the national budget for its national defense, while it spent around 70 percent for its national economy during the same period. In comparison with the 1960s, when defense spending was 19 percent of total state expenditure, a relatively small amount of the budget was allocated to the military sector in the period 1953-1960.37)

In terms of numbers, the increase in the North Korean armed forces after the armistice was insignificant, especially compared with that of South Korea (see Table 3). Furthermore, the Chinese Peoples' Volunteer Army, which had been stationed in North Korea since the end of the Korean conflict, began to withdraw as early as March 1955.38) In addition, the North Korean government utilized its soldiers in reviving its economy in order to supply needed manpower, as noted earlier. In 1953, Kim Il Sung stated that soldiers should be mobilized for the rehabilitation of the economy during intervals in their

36) Stockholm International Peace Research Institute, The Arms Trade with the Third World (New York: Humanities Press, 1971), p. 409-12. During the same period, 116 combat aircraft, 18 naval vessels, 12 tanks, and 1 missile were supplied to South Korea.

37) Pukhan chonso [North Korean Reviews], Vol. II (Seoul: Kuktong munje yon'guso, 1970), pp. $50-51$.

38) FO 371/115358, "Notes for Review of Current Intelligence," Week Ending 19 April 1955, War Office, 21 April 1955, PRO. 
combat and political drill because the most important task for North Korea at that time was to mobilize all resources for economic development. ${ }^{39}$ )

[ Table 3] Number of Soldiers in North and South Korea

\begin{tabular}{c|c|c} 
& 1953 & 1955 \\
\hline \hline North Korea & 288,720 & 316,700 \\
\hline South Korea & 350,000 & 640,000 \\
\hline
\end{tabular}

Source: FO 371/115358, 18 March 1955, PRO.

In fact, for Kim Il Sung, the first task in rebuilding the military in the years immediately after the Korean War was political indoctrination to implant in his army an absolute loyalty towards him and the party, rather than strengthening its fighting capabilities. Factionalism had pervaded the Korean People's Army (KPA), as well as the party, during the war, and again it divided along the line of Soviet-Koreans versus Yenan-Koreans. ${ }^{40)}$ Therefore, it is not surprising that there had been disputes among the army leaders on such crucial questions as "to whom the army belonged," and "what tradition it should properly inherit," as Kim Il Sung revealed later in his speech at the tenth anniversary of the founding of the Korean People's Army, 8 February 1958. According to Kim, there were those who argued that the army belonged to the Democratic National United Front, which was an organization of various democratic political parties and social organizations. Another group of factionalists allegedly argued that the KPA was properly the heir to the peasant movement which took place in northern Hamgyong province.

Concerning this problem, Kim Il Sung made it clear that: "The People's Army was

39) Works, Vol. 8, p. 60. According to an American source, it was standard practice for all military units to assist local farm cooperatives in the seasons of transplanting and harvesting. Rear area troops spent ten to fifteen days in agricultural work at harvest time. Line troops were supposed to spend one to two days a week in work. In general, half their time was spent in training and the other half in useful labor. "Leadership in North Korea: Groupings and Motivations," Office of Intelligence Research, DDRS (1975), no. 28C.

40) Joungwon A. Kim, Divided Korea: The Politics of Development 1945-1972 (Cambridge, Mass.: Harvard University Press, 1976), p. 185. From when the North Korean army was first established, there had been several organizational and personnel components within it: (1) Kim II Sung's partisan contingent; (2) about 3,000 Korean returnees from Russia led by Ho Ka-i and An Kil; (3) The Korean Volunteer Corps led by Mu Chong and Pak Il-u; and (4) several thousand independent partisan fighters from both Manchuria and North China led by Pang Ho-san, Kim Kang and Kim Ho. See Kiwon Chung, The North Korean People's Army and the Party, in Scalapino, North Korea Today, p. 108. 
organized by the Korean Workers' Party as the revolutionary armed forces of the Party to carry out....socialist revolution in Korea [emphasis supplied]." Kim also said that the People's Army was the successor to his partisans fighting in Manchuria against the Japanese. He argued that all other Korean Nationalist and Communist armed struggles had failed except his partisans. Kim clarified again this point in his 1958 speech: "Our People's Army is an army that has inherited the revolutionary traditions of the Anti-Japanese Guerrilla Army [of Manchuria] which, guided by Marxist-Leninist ideas, fought against imperialism in the interests of the workers, peasants, and other working people."41)

In sum, by eliminating all other factional elements in the army, as well as in the party through the 1956-58 purge, Kim Il Sung presented a new model for the Korean People's Army to emulate. Needless to say, it was supposed to ensure the loyalty of the army toward his party and himself.

\section{The Policy towards South Korea: A Peace Offensive}

As discussed in the above, for political and economic reasons, it is unlikely that the North Korean regime was seriously preparing for, or considering another military invasion against South Korea during the period from 1953 to 1960. Instead, Kim Il Sung proposed "peaceful unification." Then, what did Kim try to achieve by advocating peaceful unification?

To examine Kim Il Sung's objectives in supporting peaceful unification, it is necessary to understand what he meant by unification. For Kim, national unification was the basic revolutionary task. That is, all the tasks of the anti-imperialist and anti-feudal revolution had already been fulfilled in the northern half of Korea, and therefore, the fundamental task of the revolution at that current stage was to overthrow the "aggressive forces of US imperialism and their ushers and allies," and to free the people in South Korea "from imperialist and feudal oppression and exploitation," thereby achieving the country's unification along "democratic lines." 42 )

The revolution was to be achieved in South Korea, according to Kim, by raising the political consciousness of the people in the South through effective "political work." By political work, Kim Il Sung meant strengthening the influence of the northern half of Korea on the southern people, and inducing the broad popular masses of South Korea to

41) See Kim's speech titled, "The Korean People's Army Has Inherited the Anti-Japanese Armed Struggle," February 8, 1958, Selected Works, Vol. 2, pp. 64-101.

42) Selected Works, Vol. 2, p. 504. 
support North Korea. For this purpose, the "democratic base" had to be fortified by promoting socialist construction in the northern territory of Korea. In order to unify Korea "peacefully," Kim asserted, these two tasks--the consolidation of the democratic base and effective political work--had to be accomplished. ${ }^{43)}$ Here, we can clearly see that the democratic base advocated by Kim was no more than a socialist revolutionary base from which revolutionary influence could be exerted upon South Korea to attain unification on Communist terms. The relationship between the revolutionary base and unification was fully articulated later: Kim announced, in October 1966, the strategy of three revolutions; (1) building a revolutionary base in North Korea; (2) fomenting a revolution in South Korea; and (3) strengthening ties with revolutionary forces in the world arena. In short, peaceful unification involved a sustained political campaign that would culminate in a revolution to overthrow the "enemies of the people."44)

As implied above, the political campaign had two aims--i.e., to organize the South Koreans under Communist leadership, and to emphasize the struggle against "American imperialism"--which had probably been influenced by lessons from the Korean War. First, through the negative experience of the Korean War, Kim Il Sung learned that unifying Korea under Communist rule would be difficult without organizational work to raise the revolutionary consciousness of the masses in the South. Kim once confessed:

In the early days of the war, when we....drove the enemy into the narrow strip along the Rakdong River, if we had organized properly the people in the southern half [of Korea], if not all but at least some section of them, to rise up in strikes and carry on resistance movements, the enemy would have had no alternative but to pull out. But we failed to do so. ${ }^{45)}$

Secondly, the Kim regime had regarded the United States as the most formidable enemy of unification. Kim certainly could not forget that, had it not been for the American intervention, his goal of unification by force would probably have been accomplished. In 1954, Kim Il Sung conceded that unification of Korea would not be accomplished in a short period because the U.S. was supporting the South Korean regime. To him, "American imperialism," whose strength could not be underestimated, was the major enemy of Korean unification. Accordingly, until "American imperialism" could be effectively isolated by revolutionary forces, the chance of unification was remote--"a long, difficult, and hard road

43) Ibid., p. 595

44) Works, Vol. 20, pp. 287-293.

45) Selected Works, Vol. 1, 498. 
ahead."46) Given this perception, Kim tried to alienate the South Koreans from the U.S. by continuously accusing the U.S. of being a major obstacle to peaceful unification. This was supposed to appeal to nationalist sentiments in South Korea.47)

As a part of the political campaign, the North had made an effort to establish contacts and bases of operation in the South. In particular, Communist agents considerably increased their activities in the ROK from 1957, encouraged by successful political and economic recovery in the North. A total of 236 Communist-controlled agents were caught in the ROK during 1957, an increase of 25 to 35 percent over previous years. The northern agents dispatched to the South consisted mostly of former South Korean residents who had gone to the North during the Korean War. These agents tried to stir up anti-Rhee government sentiment by advertising both the accomplishments of North Korea and its peaceful unification formula. Few of their missions, according to a captured high-level Korean agent, were related to military or terrorist acts.48)

Another important tactic in the North Korean peace offensive was to win support from the South Korean populace by making North Korea economically attractive. Kim Il Sung argued:

When we carry out economic construction well and improve the people's life, no force on earth will be able to suppress the revolutionary spirit of the people in South Korea who, longing for the northern half, will rise against the reactionary regime in South Korea, and we will be able to easily solve the problem of the livelihood of the South Korean people after the country is reunified. ${ }^{49)}$

In this context, the Pyongyang regime's propaganda constantly stressed that conditions in the North were akin to "paradise" in comparison with the "miserable and hopeless" situation of the South. The North Korean regime included the item of economic and cultural exchange between North and South Korea--e.g., establishing commercial and financial relations, free postal communication, and free travel of inhabitants--whenever it made proposals of peaceful unification. North Korea also offered the export of items in short supply in the South such as electricity, coal, cement, and chemical fertilizers. ${ }^{50)}$

46) Selected Works, Vol. 1, pp. 496-98.

47) For this point, see Scalapino and Lee, Communism in Korea, p. 547.

48) Byung Chul Koh, The Foreign Policy of North Korea (New York: Praeger, 1969), p. 146; RG 59, 795B.00/2-1358, February 13, 1958, NA; "Counter Intelligence Digest" by The Pacific Air Force, October 10, 1958 in RG 59, 795.00/11-2058, November 20, 1958, NA.

49) Selected Works, Vol. 1, p. 499. 
With the allegedly successful performance of its economic plans, the Kim Il Sung regime's propaganda focusing on economic matters became more insistent and aggressive in the end of 1950s. For example, in February 1958, Kim said: "If the South Korean people see with their own eyes the superiority of our socialist system, it is clear that they would raise their hands in favor of us, not for Syngman Rhee."51) Considering the poor living standards of North Korea, as examined earlier, this statement was quite a bold one. Nevertheless, Kim presumably resorted to such propaganda in order to lure the South Koreans psychologically, relying on the fact that they were also suffering from economic difficulties. In the same month, Pyongyang put forward a unification proposal involving: (1) simultaneous withdrawal of all foreign troops from Korea; (2) all-Korean free elections under the supervision of neutral nations; (3) negotiations between North and South Korea regarding North-South economic and cultural exchanges, and freedom of movement; and (4) reduction of North and South Korean armed forces to minimum levels. The North Korean proposal was dramatized by the joint announcement between Kim Il Sung and Zhou Enlai that the Chinese Communist troops would be withdrawn from North Korea by the end of 1958.52)

In addition, the Kim regime was relatively free to launch various peaceful offensives partly because the Syngman Rhee regime in the South was doing little about the unification issue except reacting negatively to North Korean schemes, and issuing calls to March north. Thus, the North Korean peaceful policy during this period was successful to the extent that North Korea had seized the strategic initiative in respect of its relations with South Korea and the unification issue.

\section{Conclusion}

Since the end of the Korean conflict, Kim Il Sung had advocated peaceful unification and postwar rehabilitation. A close look at developments in the northern half of Korea

50) For various unification proposals of North Korea, see For the Peaceful Unification of Korea (Pyongyang: Foreign Languages Publishing House, 1957); see also U.S. Department of State. The Record on Korean Unification, 1943-1960: Narrative Summary with Principal Documents (Washington D.C.: U.S. Government Printing Office, 1960).

51) Works, Vol. 12, p. 59.

52) This Communist peace proposal touched off a series of consultations among the Sixteen nations participated in the Korean War for a possible unification formula, which lasted about a year. Many of the Sixteen showed flexible views on the Korean problem, proposing some unification measures which were more favourable to the North than the South. For a full text of the North Korean proposal, see US Department of State, The Record on Korean Unification, pp. 211-14. 
shows that the Communist regime had indeed given priority to consolidating its political power and restoring the economy, contrary to the Rhee regime's charge that the Communists were preparing for another aggression in the guise of a peaceful policy. Such a policy directive of North Korea mainly resulted from its experience in the Korean War. The war not only proved that unification by military means was difficult, if not impossible, but also caused serious damage to North Korean political and economic bases, a damage which should be recovered as soon as possible for survival.

In terms of rebuilding political base, Kim Il Sung consolidated his power by purging rival factions with skilful manoeuvres while reorganizing the Korean Workers' Party which had been severely damaged during the war. Thus, Kim could establish undisputed control over North Korea by 1958. As for the economic sector, through a series of development plans, North Korean economy rapidly recovered from war destruction. But it should be noted that the postwar rehabilitation was focused on industrial development at the expense of the living conditions of the people. Although the rebuilding of military capabilities was also one of its main goals, it seems that the North placed less emphasis on a military build-up than on post-war rehabilitation during the period from 1953 to 1960. At that time, North Korea heavily depended on China and the Soviet Union for its defence.

As for unification policy, Kim Il Sung tried to communize the South through a psychological warfare with peace offensive rather than a military one. The Pyongyang regime waged a political campaign to stir up anti-American and anti-South Korean government sentiment, and attempt to win support from the South Koreans by making North Korea economically attractive.

It is difficult to estimate the influence of the peace propaganda and economic appeals to the South Korean people. But it cannot be denied that South Korea was, at least potentially, vulnerable to the North Korean peace offensive owing to the misconduct of the Syngman Rhee government. At that time President Rhee paid little attention to the social and economic demands of his people partly because of his preoccupation with the military threat from the North. The consequences were serious enough to lead an American observer draw the following conclusion:

The people [in the South] have little faith in the government or sense of identification with it.....There is little awareness of improvement in the lot of the average man; on the contrary, dissatisfaction is sharpened by increased awareness of high living standards elsewhere. Discontent with the present state of affairs, in the absence of constructive and effective leadership, might eventually result in the abandonment of Free World principles in favor of extremist ideologies.53) 
Fortunately for South Korea, however, it was most unlikely that the Communist regime gained any tangible support from the southern populace. According to a US Embassy assessment, despite increased Communist subversive activities, there was no evidence that the integrity of the government, the military establishment, or other ROK institutions was endangered. ${ }^{54)}$

The northern Communists themselves were largely responsible for this failure. Their behavior toward the South Korean population during the Korean War had been harsh, and had instilled a deep and irreparable antagonism towards the Communists in the people of the South. Thus, most South Koreans were not persuaded by North Korean propaganda, even if they were not satisfied with the Rhee government.

53) RG 59, "Situation and Short-term Prospects of Korea," prepared by Ambassador Dowling, 795B.00/11-2157, November 21, 1957, NA.

54) RG 59, 795B.00/2-1358, February 13, 1958. 


\section{References}

\section{Primary Sources}

\section{(1) Unpublished Documents}

Department of State, Office of Intelligence Research, Division of Research for Far East, Intelligence Report Series, National Archives, Washington, D.C.

FO 371, Foreign Office Files, Far Eastern Korea, Public Record Office, London.

RG 59, General Records of the Department of State. Decimal File, National Archives, Washington, D.C.

US Declassified Documents Reference System.

\section{(2) Published Documents}

Bank of Korea, Kyongje t'onggye yonbo [Economic Statistics Yearbook]. Seoul: Bank of Korea, 1962.

Choson chungang yon'gam [The Korean Central Yearbook]. Pyongyang: Choson chungang tongshinsa, 1961.

For the Peaceful Unification of Korea. Pyongyang: Foreign Languages Publishing House, 1957.

Kim, Il Sung. Kim Il Sung's Works. Pyongyang: Foreign Languages Publishing House, various years.

. Selected Works. Pyongyang: Foreign Languages Publishing House, various years.

R.O.K Office of Public Information, Taet'ongryong Rhee Syngman paksa tamhwachip [Collection of Statements by President Syngman Rhee], Vol. I, Seoul: Office of Public Information, 1953.

U.S. Department of State. Foreign Relations of the United States, 1952-1954, Vol. XV: Korea (two parts). Washington, D.C.: Government Printing Office, 1984.

. The Record on Korean Unification, 1943-1960: Narrative Summary with Principal Documents. Washington D.C.: U.S. Government Printing Office, 1960.

\section{Secondary Sources}

Cumings, Bruce. The Origins of the Korean War, Vol. II: The Roaring of the Cataract, 1947-1950. Princeton: Princeton University Press, 1990.

Foot, Rosemary. A Substitute for Victory: The Politics of Peacemaking at the Korean Armistice Talks. Ithaca and London: Cornell University Press, 1990. 
Gaddis, John Lewis. Strategies of Containment: A Critical Appraisal of Postwar American National Security Policy. Oxford: Oxford University Press, 1982.

Goto, Fujio. Estimates of the North Korean Gross Domestic Product, 1956-1959. Kyoto: Kyoto Sangyo University Press, 1990.

Hong, Yong-Pyo. State Security and Regime Security: President Syngman Rhee and the Insecurity dilemma in South Korea. London: Macmillan, 2000.

Kim, Hak-Joon. The Unification Policy of South and North Korea: A Comparative Study. Seoul: Seoul National University Press, 1977.

Kim, Joungwon A. Divided Korea: The Politics of Development 1945-1972. Cambridge: Harvard University Press, 1976.

Koh, Byung Chul. The Foreign Policy of North Korea. New York: Praeger, 1969. . "The Korean War as a Learning Experience for North Korea." Korea \& World Affairs, Vol. 3, No. 3 (Fall 1979).

Kuark, Yoon T. "North Korea's Industrial Development During the Post-War Period." In Scalapino, Robert A. ed. North Korea Today. New York: Praeger, 1963.

Lee, Chong-Sik. "Stalinism in the East: Communism in North Korea." In Scalapinp, Robert A. ed. The Communist Revolution in Asia: Tactics, Goals and Achievements. Angled Cliffs: Prince Hall, 1965.

Lee, Pong S. "Overstatement of North Korean Industrial Growth, 1946-63," Journal of Korean Affairs, Vol. 1, No. 2 (July 1971).

. "An Estimate of North Korea's National Income." Asian Survey, Vol. 12, No.

6. (June 1972).

Pukhan chonso [Study of North Korea]. Vol.2. Seoul: Kuktong munje yon'guso, 1970.

Scalapino, Robert A. and Lee, Chong-Sik. Communism in Korea, Part I: The Movement. Berkeley: University of California Press, 1972.

Stockholm International Peace Research Institute. The Arms Trade with the Third World. New York: Humanities Press, 1971.

Suh, Dae-Sook. Kim Il Sung: The North Korean Leader. New York: Columbia University Press, 1988.

Ulma, Adam B. Expansion and Coexistence: Soviet Foreign Policy, 1917-1973. 2nd ed. New York: Praeger, 1974. 